10IKC-261

\title{
APPLICATION OF WEAK LEACHES IN KIMBERLITE EXPLORATION
}

\author{
${ }^{1}$ de Souza HAF, ${ }^{2}$ Fedikow MAF, ${ }^{3}$ Ryder J, ${ }^{1}$ Turner N, ${ }^{1}$ Halliday M \\ ${ }^{1}$ SGS Mineral Services, Toronto, Canada; ${ }^{2}$ Mount Morgan Resources, Lac du Bonnet, Canada \\ ${ }^{3}$ Dianor Resources, Val-d'Or, Canada
}

\section{INTRODUCTION}

Identification of thin, subcropping kimberlitic bodies can be problematic particularly in areas of thick cover, commonly represented by transported glacial overburden in the northern hemisphere or thick saprolite in areas of tropical weathering. Occasionally, these thin, 2-3m, subhorizontal sills and dykes might develop well preserved indicator mineral trails but location of these bodies can be difficult either because the geophysical methods used might lack the resolution to identify them or other factors mask the kimberlitic signal. With increased reliance on geophysical methods in regional exploration, complimentary techniques are needed, where interpretation of the geophysical signal is uncertain because of geological variability in the kimberlitic targets (Reed \& Witherly 2007, Petit 2008). An example of this in Ontario kimberlites was noted by Sage (1999) whereby some display magnetic highs while others have magnetic lows. Therefore, use of geochemical methods can be important by providing independent evidence that kimberlite is present. In other cases where there might be so many geophysical targets that the cost of drill testing these targets would be prohibitive, geochemical methods can play a role in ranking targets.

\section{WEAK LEACHES AND THE MMI PROCESS}

In terrains with exotic cover, classic soil exploration methods using aqua regia digests have had very mixed record and from the mid-nineties this spurred a resurgence in the use of weak partial and sequential leaches using more sensitive ICPMS instrumentation that was ideal for analysis of the low levels of ions extracted. An industry wide program under the auspices of the Canadian Mining Industry Research Organization (CAMIRO) demonstrated that the use of weak leaches was effective in detecting buried mineralization even under $30-40 \mathrm{~m}$ of cover (Cameron et al, 2004). The advantages of weak leaches are that they target the mobile metal ion population. These are recently arrived metals that are yet to be incorporated into the soil particle and they provide a direct link to underlying mineralization (Mann et al 2005). As discussed by Mann (2010) the Mobile Metal Ion method is a ligand based weak leach for soils that extracts ions that are loosely bound to soil particle surfaces. Extracting just the mobile ions in the soil improves the signal to noise ratio by reducing the background analytes leading to improved spatial and amplitude resolution. Using strong multiple ligands in the extracting solution avoids readsorption effects and keeps the analytes in solution. This is a key difference between MMI and other leaches such as ammonium acetate that have been used in kimberlite studies (McClenaghan et al 2006, Hattori et al 2009)

It is important to note that a consequence of using a weak leach is that the mobile metal ion population in solution is in the sub ppb to low 


\section{0 $^{\text {th }}$ International Kimberlite Conference, Bangalore - 2012}

ppm range and the use of ICP-MS for analysis of the solution is essential. The advantages of ICPMS for analysis of heavy elements notably the rare-earth elements (REE) has been evident since the technology became available in the mideighties (Caughlin 2010). Current instrumentation has greatly improved sensitivity and has extended the range of elements that can be analyzed to over fifty for the MMI-M extraction. For elements such as $\mathrm{Cr}$ that are important in kimberlite exploration, interference effects lead to higher detection limits; the use of Dynamic Reaction Cells suppresses these interferences and has lowered the detection limit to $1 \mathrm{ppb}$ for $\mathrm{Cr}$ (Turner \& Prince 2011).

A key aspect of the MMI process is the sampling protocol using a consistent depth based sampling typically $10-25 \mathrm{~cm}$ from the true soil interface (Mann et al 2005). The CAMIRO program (Cameron et al 2004) confirmed the importance of sampling depth, but indicated that it might vary according to the climatic regimes and landscape environments. Therefore, an orientation program to identify the most representative and highest-contrast sampling depth is recommended prior to starting large scale sampling.

\section{KIMBERLITE GEOCHEMISTRY}

Kimberlites offer an interesting target from a geochemical exploration perspective. Their geochemistry (Mitchell 1986, 1995) combines a high level of incompatible trace elements (such as $\mathrm{Nb}, \mathrm{Y}, \mathrm{Rb}, \mathrm{Ba}$, light REE) with an ultramafic major and minor element content (high $\mathrm{Mg}, \mathrm{Cr}$, $\mathrm{Ni})$. This unusual geochemistry also provides a good geochemical contrast with surrounding lithologies into which they have been emplaced when interpreting surficial soil geochemical results. To be able to separate kimberlitic signatures from other ultramafic rocks in the surface requires consideration of incompatible trace element patterns especially those of the rare earth elements.
Diamond bearing rocks are characterized by highly enriched light rare earth element (LREE) patterns and depletion of the heavy rare earth elements (HREE) whereas many other ultramafic suites typically have low REE contents. Normalized rare earth plots have not been used in interpretation of weak leach data but we demonstrate here that they are a useful way of recognizing the kimberlitic influence in the weak leach signal.

\section{CASE STUDIES}

The two case studies discussed here were over kimberlites in the Lake Temiskaming Structural Zone in north east Ontario, Canada, close to the Quebec border. The zone contains approximately 50 identified kimberlites. The MMI studies presented here were used by Dianor Resources Inc., between 2003 \& 2004, looking for innovative methods to quickly select or prioritize targets on their properties.

\section{C14 KIMBERLITE}

The $\mathrm{C} 14$ kimberlite pipe is one of several kimberlite occurences northeast of Kirkland Lake in the Kirkland Lake kimberlite field (McClenaghan 1999). Deep glacial erosion has resulted in a subcrop that is $20-30 \mathrm{~m}$ below the surrounding plagioclase porphyry bedrock. The kimberlite pipe is covered by variable glacial sediments $30-40 \mathrm{~m}$ thick. It was discovered by a combination of aeromagnetic surveys and kimberlite indicator mineral trails. Petrographic and geochemical work confirm the pipe as kimberlitic with an upper diatreme facies (heterolithic tuffsitic kimberlite breccia) and lower hyperabyssal kimberlite. An MMI orientation program was run at $25 \mathrm{~m}$ spacings over the kimberlite to determine the best depth for sampling. Samples were collected at $0-10 \mathrm{~cm}, 10-$ $20 \mathrm{~cm}$, and $20-30 \mathrm{~cm}$ depths from the soil/organic material interface at the surface. They were 


\section{0 $^{\text {th }}$ International Kimberlite Conference, Bangalore - 2012}

submitted for the extended MMI D leach which was used for diamond exploration at the time, extracting 20 key elements including some REEs.

The $0-10 \mathrm{~cm}$ data did not define the surface projection of the pipe along the sampling transcept. On the other hand, the $10-20 \mathrm{~cm}$ data (Fig 1) showed a strong ultramafic anomaly $(\mathrm{Mg}$, $\mathrm{Cr}, \mathrm{Co}$ ) over the central part of the pipe. The REE were elevated over the central part of the pipe but the largest anomalies were situated over the flanks. The ultramafic anomaly was not evident at the $20-30 \mathrm{~cm}$ depth but the REEs showed a pattern similar to the $10-20 \mathrm{~cm}$ line. It is evident that the $10-20 \mathrm{~cm}$ depth is the optimal depth for sampling for the MMI process in this area.

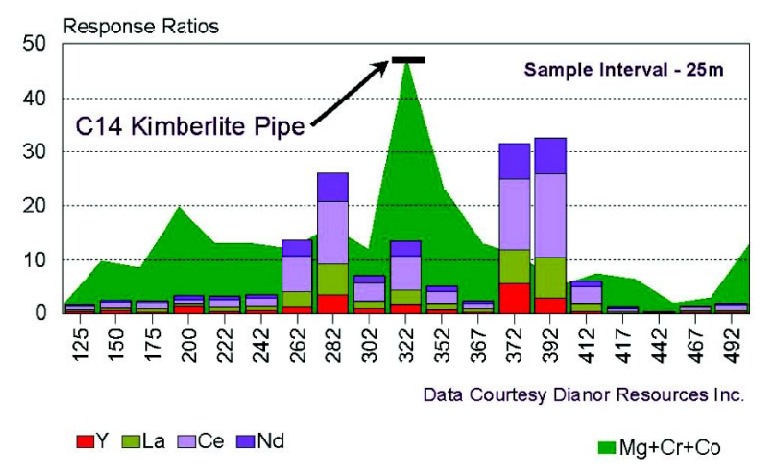

Fig. 1. MMI response ratios (ratio of element to the lowest quartile background data) for the $\mathrm{C} 14$ kimberlite for selected elements sampled at 10-20 cm depth.

\section{PACAUD KIMBERLITE DYKE SWARM}

A short MMI line was run over the Pacaud kimberlite dyke swarm, which occurs about 20 $\mathrm{km}$ south of the town of Kirkland Lake. The dykes intrude the Round Lake Batholith which ranges from tonalite to granodiorite in composition (Berger 2006) but is described as granite in the Pacaud property (Henrikson 2003). The dyke swarm occurs between the Kirkland Lake kimberlite cluster situated $35 \mathrm{kms}$ to the $\mathrm{NE}$ and the Cobalt - New Liskard kimberlite cluster 45 $\mathrm{kms}$ to the SE of the Pacaud property. Petrographic analysis of the Purcell and other dykes in the vicinity confirm them as highly serpentinized xenolithic macrocrystic hyperabyssal kimberlites
(Dianor 2004). Indicator mineral chemistry from the Purcell dyke suggests that it could potentially host diamonds.

MMI samples were collected at $10-20 \mathrm{~cm}$ depth along a $100 \mathrm{~m}$ line at $10 \mathrm{~m}$ intervals in thin glacial cover consisting mainly of clay (approx $0.5 \mathrm{~m}$ ) over the Purcell dyke. The dyke was intersected at a depth of $20 \mathrm{~m}$ below surface in granite and is about $2 \mathrm{~m}$ wide at this location. The MMI-M multi-element extraction with enhanced detection limits was used and 39 elements determined. The results in Figure 2 show a strong ultramafic (Mg, Ti, Cr, Ni, Co, Pd) and kimberlite $(\mathrm{Nb}, \mathrm{Y}, \mathrm{Rb}, \mathrm{Ba})$ response over the surface projection of the Purcell dyke. The total REE and MMI-D element response is also anomalous over the Purcell dyke and indicates two other potential targets to the east. These are likely extensions of kimberlitic dykes occurring parallel to the Purcell dyke intersected at shallow depths (3-8m) about $75 \mathrm{~m}$ to the south and considered part of the Purcell dyke set.
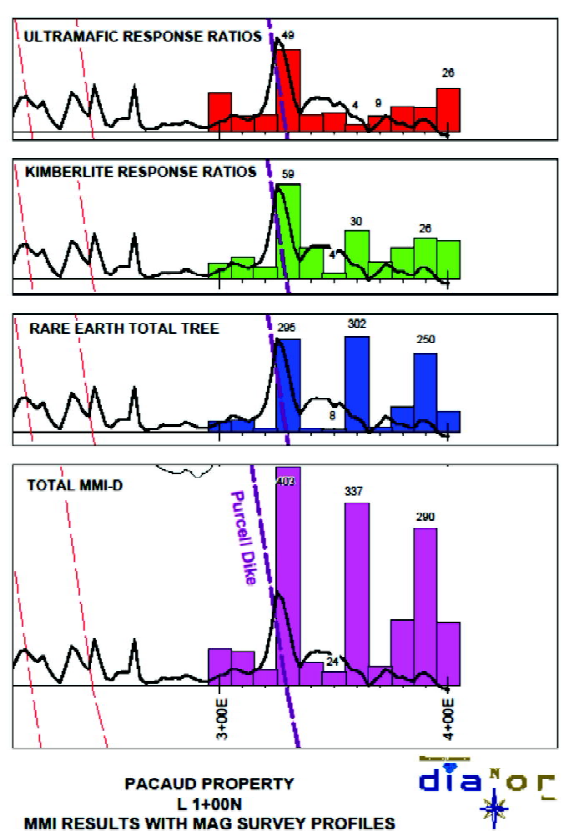

Fig 2. MMI results over the Purcell dyke set in Pacaud township, Ontario. 


\section{0 $^{\text {th }}$ International Kimberlite Conference, Bangalore - 2012}

The combination of the strong ultramafic and kimberlite response in addition to the REE response is a strong indication of kimberlite. The Purcell dyke also has an anomalous magnetic response in the surface magnetic survey, but other kimberlites to the west have a less significant anomaly.

\section{REE RESPONSE}

The MMI surveys over the $\mathrm{C} 14$ and Pacaud kimberlites both showed a strong REE response over the kimberlite. Both are also intruded into felsic magmatic rocks, a plagioclase porphyry and granites of the Round Lake Batholith respectively. Both lithologies are potential sources of the REE anomalies. In the case of the $\mathrm{C} 14$ anomalies that are higher at the flanks, it could be argued that they originated from the felsic host rock. The Pacaud dykes are so narrow that the host granite could easily have been the source of the elevated REEs. One way to resolve this question is to look at the REE data as normalized REE patterns as is commonly done in petrogenetic studies but thus far not applied in interpreting soil survey geochemical data. Chondrite normalized data (McDonough \& Sun 1995) were used as we are seeking to evaluate the differences between the soil data and kimberlitic values.

For the C14 kimberlite survey only nine REEs were determined (Fig 3) but they are sufficient to define the REE pattern. A limited number of REE values were determined for the C14 diatreme facies by McClenaghan et al (1999) and these are also plotted in Figure 3, extrapolating for missing values. The C14 REE pattern is lower but parallel to the field of diamondiferous kimberlites (see Fig 4).

The soil REE data over $\mathrm{C} 14$ have a pattern that is distinctly alkaline with an enrichment in the LREE. They plot parallel to the REE values from $\mathrm{C} 14$ but are lower in abundance. By contrast the REE patterns from samples on the flanks are flat lying. The fact that the MMI REE data display

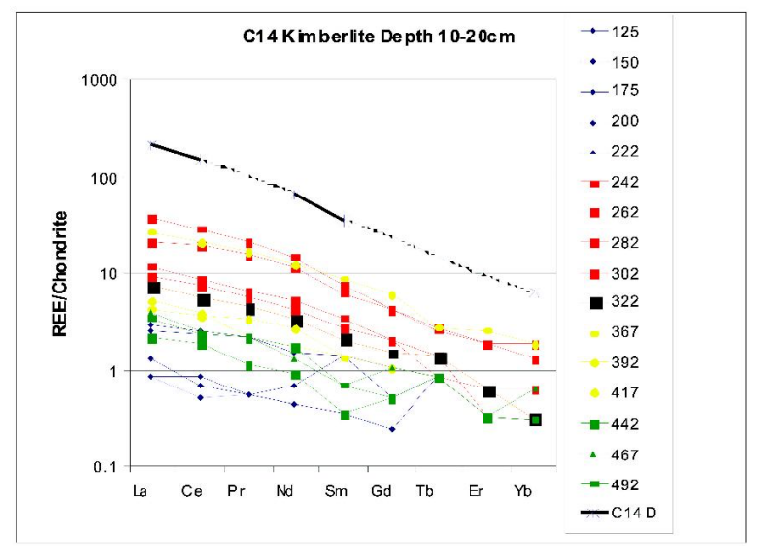

Fig 3. REE/chondrite plot for the C14 MMI data. C14D is from the diatreme facies of the C14 pipe ( McClenghan, 1999). Where the HREE data are below detection a value of half the detection limit is used.

a similar pattern to the $\mathrm{C} 14$ kimberlite indicate its affinity to and derivation from the pipe.

The question of why the REE response over the flanks is stronger than over the central part of the $\mathrm{C} 14$ pipe remains. It may be related to compositional variations in the diatremic facies of the kimberlite. The Sader et al. (2007) study of groundwaters at $\mathrm{C} 14$ noted that they fell into two groups of mildly alkaline $(\mathrm{pH} \mathrm{8-10)}$ and highly alkaline ( $\mathrm{pH} 10-12)$ groups possibly as a result of compositional variations. On the other hand shattering of the margins during kimberlite emplacement creates a more permeable zone at

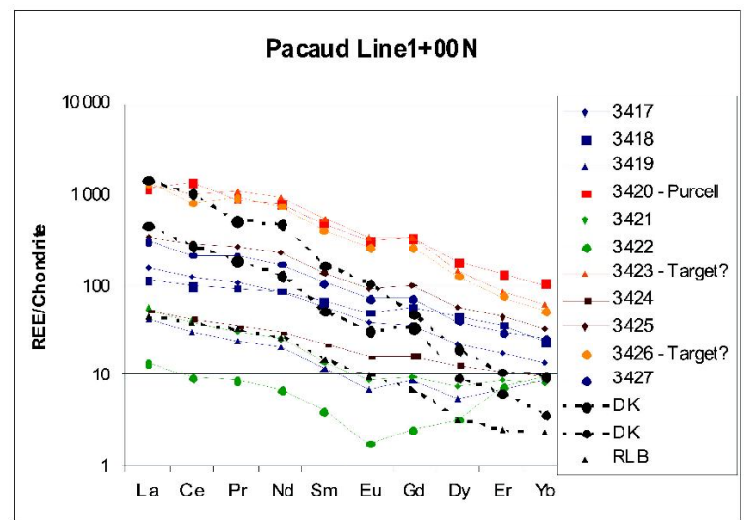

Fig 4. REE/chondrite plot for the Pacaud MMI data. DK is the field for diamondiferous kimberlites. RLB is the Round Lake batholith from Berger(2006) 
the flanks allowing mobile ions to travel more easily to the surface. Sader et al (2011) cite this as a reason for an upwelling of groundwater measured at the flanks of the Attawapiskat kimberlites that were also marked by surface soil flank REE anomalies (Hattori et al 2009).

Figure 4 shows the chondrite normalized MMI REE data patterns for the Pacaud MMI survey line. Also shown is the field for diamondifereous kimberlites (Mitchell, 1986, 1995) and REE data for the Round Lake Batholith in which these dykes occur. The Purcell dyke and two targets $(3423,3426)$ are clearly anomalous not just in their REE abundances but also in their patterns. They differ significantly from the Round Lake Batholith pattern which is lower in abundance and flatter than the Purcell pattern although still alkaline (Berger 2006); the MMI REE patterns on the flanks are similar to the Round Lake batholith patterns but enriched in the HREE. The Pacaud MMI anomalies are similar to kimberlites in their $\mathrm{La}$ and $\mathrm{Ce}$ abundances but are enriched in the HREE relative to kimberlites and the host Round Lake Batholith. This might reflect a contribution from xenoliths, notably garnet rich rocks that might have hosted the HREE, but extensive alteration in the dykes has altered all but the most resistant minerals.

\section{CONCLUSION}

MMI weak leach data are clearly able to distinguish kimberlite from host rocks even though thick exotic cover that is less than 10,000 years old. The unusual geochemical signature of kimberlite is well reflected in the surficial soil geochemical data and clearly allows us to discriminate it from other ultramafic rock types and most other lithologies that lack the distinctive alkaline rock LREE enrichment. MMI surveys are also a capable of high resolution geochemistry with both spatial resolution and amplitude as shown with the Pacaud dyke swarm.
The stronger MMI response over the kimberlite compared to that over the felsic hosts suggests that the nature of low temperature alteration processes in kimberlites is the driving force in liberating ions and propelling them to the surface creating mobile metal anomalies in the soil cover.

\section{References}

Berger, B.R. 2006. Geological synthesis along Highway 66 from Matachewan to Swastika; Ontario Geological Survey, Open File Report 6177, $125 \mathrm{p}$.

Caughlin, B.L. 2010. Developments in analytical technology. Geochemistry: Exploration, Environment, Analysis, 10, 137-141.

Cameron, E.M., Hamilton, S.M., Leybourne, M.I., Hall, G.M. \& McClenaghan, M.B. 2004. Finding deeply buried deposits using geochemistry. Geochemistry: Exploration, Environment, Analysis, 4, 7-32.

Dianor, 2004. Study confirms Pacaud dykes as kimberlites with diamond inclusion mineral grains. Press Release 2004-05

Hattori K.H., Hamilton S., Kong J. \& Gravel J., 2009. Soil geochemical survey over concealed kimberlites in the Attawapiskat area in northern Canada. Geochemistry: Exploration, Environment, Analysis, 9, 139-150

Henriksen, G.N., 2003. Report on the 2003 prospecting and mapping program on the Laskowski prospect, Globex Mining Enterprises Inc., Larder Lake mining division, Pacaud township, Ontario. 10p

Mann, A.W., 2010. Strong versus weak digestions: ligand-based soil extraction geochemistry. Geochemistry: Exploration, Environment, Analysis, 10, 17-26

Mann, A.W., Birrell, R.D., Fedikow, M.A.F. \& de Souza, H.A.F. 2005. Vertical ionic migration: soil anomalies, and sampling depth for mineral exploration. Geochemistry: Exploration, Environment, Analysis, 5, 201-210.

McClenaghan, M.B., Kjarsgaard, I.M., Stirling, J.A.R; Pringle, G; Kjarsgaard, B A; Berger, B.,1999. Mineralogy and geochemistry of the $\mathrm{C} 14$ 


\section{0 $^{\text {th }}$ International Kimberlite Conference, Bangalore - 2012}

kimberlite and associated glacial sediments, Kirkland Lake, Ontario. GSC Open File 3719, 147p

McClenaghan, M.B., Hamilton, S.M., Hall, G.E.M., Burt, A.K. \& Kjarsgaard, B.A., 2006. Selective leach geochemistry of soils overlying the 95-2, B30 and A4 kimberlites, northeastern Ontario. Open File 5069, Geological Survey of Canada, Ottawa, Canada.

McDonough,W.F. \& Sun, S.S., 1995. The composition of the Earth.

Chemical Geology, 120, 223-253.

Mitchell, R.H. 1986. Kimberlites: Mineralogy, Geochemistry and Petrology, Plenum Publishing, New York.

Mitchell, R.H. 1995. Kimberlites, orangeites, and related rocks, Plenum Press, New York.

Pettit, W., 2009. Geophysical signatures of some recently discovered large ( $>40 \mathrm{ha}$ ) kimberlite pipes on the Alto Cuilo concession in northeastern Angola. Proceedings of the $9^{\text {th }}$ IKC , Lithos 112s, 106-115.

Reed, L.E., \& Witherly, K.E., 2007. 50 years of kimberlite geophysics, a review. In B. Milkereit ed, Exploration in the New Millenium, Proceedings of the Fifth Decennial International
Conference on Mineral Exploration, 679-689

Sader, J.A., Leybourne, M.I., Mcclenaghan, M.B. \& Hamilton, S.M., 2007. Low-temperature serpentinization processes and kimberlite ground water signatures in the Kirkland Lake and Lake Timiskiming kimberlite fields, Ontario, Canada; implications for diamond exploration. Geochemistry: Exploration,Environment, Analysis, 7, 3-21.

Sader J.A., Hattori K.H., Kong J.M., Hamilton S.M. \& Brauneder K., 2011. Geochemical responses in peat groundwater over Attawapiskat kimberlites, James Bay Lowlands, Canada and their application to diamond exploration. Geochemistry: Exploration, Environment, Analysis, 11, 193-210

Sage, R.P. 1999. Project 93-12. Structural patterns and kimberlite emplacement; in Summary of Field Work and Other Activities; Ontario Geological Survey, Miscellaneous Paper 169, p.224-229.

Turner, N. \& Prince, P., 2011. Novel geological exploration applications of mobile ion technology using dynamic reaction cell ICP-MS. Abstracts, $25^{\text {th }}$ IAGS 2011 (ed Sarala, P, Ojala, VI, \& Porsanger, ML), 125-126 